\title{
A COMPARISON OF ANCIENT AND MODERN WEAPONS IN THE EFFECTIVENESS OF PRODUCING BATTLE CASUALTIES
}

\author{
P. B. ADAMSON
}

SUMMARY: A brief comparison is made between war wounds in antiquity and at the present time. Variation in anatomical distribution of injuries and the marked improvement in mortality figures are discussed. Emphasis is placed on improved surgical technique and treatment being mainly responsible for the drop in mortality, with protective armour playing a sibsidiary role.

Injuries from weapons may be roughly divided into two main groups according to the distance apart of the assailants. All wounds from swords, daggers, stones and spearthrusts are the result of attack from close quarters. Missiles discharged by hand or machine may be classified as long-range weapons and produce injuries at a distance: arrows, spearcasts, javelins and slingshots come into this category.

The earliest records of large numbers of battle injuries are mentioned in the "Iliad" of Homer, and probably reflect the historical event of the Siege of Troy c. 1200 B.C., although the military descriptions apply to the age of Homer himself ${ }^{\perp}$. Human remains of earlier times have occasionally been found in archaeological excavations, of which Egyptian diggings have produced the majority ${ }^{2}$. The war injuries mentioned in the Iliad allow direct comparison between the type of weapon and the anatomical site of injury produced by that weapon, and may be taken as respresenting battle casualties in the 8th century B.C. Homer, however, has been selective in his description of casualties, for the Iliad only reports the last few days of the long drawn-out battle for Troy which lasted for almost ten years; furthermore, the emphasis of the epic is concentrated on the kings of the opposing forces and the leaders of the fighting units. Nevertheless, it appears quite valid to compare the actual injuries described by the poet, bearing in mind that the protective armour and personal weapons of the military leaders are always likely to be of higher quality than those of the ordinary soldier.

The epic of the Iliad was continued by Homer in the Odyssey, and by Virgil in the Aeneid. Virgil flourished at the very end of the first millenium and lived into the early years of Christianity. As his life spanned a period of unrest in the Roman Empire, he was well placed to observe military operations undertaken by the Roman armies, and consequently the Aeneid, although based on the Iliad and on the past glories of the Romans themselves, reflects the military machine of Rome in the last century of the first millenium B.C.

An analysis of injuries produced by selected weapons mentioned in the Iliad and the Aeneid is shown in Tables I and II. Some battle casualties have had to be omitted from these tables because of insufficient detail in their description. However, from the injuries that have been clearly described by Homer and Virgil, it appears that the majority of lethal wounds were almost immediately fatal, before the victim could even be taken to the surgeon. The spear was the most important weapon of attack described in the Iliad, whereas the sword was more frequently used in the Aeneid. The discharge of a spear or javelin from the hand did not necessarily leave a warrior entirely dependent on his sword, since it was customary for the infantry to carry at least two spears into battle. This form of armament was usual among those fighting at Troy, is also 
Table I

Battle casualties in the " Miad" and "Aeneid"

\begin{tabular}{|c|c|c|c|c|c|c|c|}
\hline & & Close-cc & nbat injl & & Long-rang & injuries & Total \\
\hline & & Spearthrust & Sword & Stone & Spearcast & Arrow & \\
\hline Head/neck. & $\begin{array}{ll}\text { Lethal } & - \text { Iliad } \\
\text { Aeneid } \\
\text { Wounded }- & \text { Iliad } \\
& \text { Aeneid }\end{array}$ & $\begin{array}{r}12 \\
4 \\
2 \\
-\end{array}$ & $\begin{array}{l}13 \\
23 \\
-\end{array}$ & $\begin{array}{r}5 \\
3 \\
2 \\
-\end{array}$ & $\begin{array}{r}13 \\
3 \\
10 \\
1\end{array}$ & $\frac{2}{3}$ & $\begin{array}{r}45 \\
36 \\
14 \\
2\end{array}$ \\
\hline Chest. & $\begin{array}{ll}\text { Lethal } & \text { Iliad } \\
& \text { Aeneid } \\
\text { Wounded }- & \text { Iliad } \\
& \text { Aeneid }\end{array}$ & $\begin{array}{r}19 \\
3 \\
1 \\
-\end{array}$ & $\begin{array}{l}1 \\
9 \\
-\end{array}$ & $\frac{-}{1}$ & $\begin{array}{r}10 \\
13 \\
2 \\
1\end{array}$ & $\begin{array}{r}2 \\
2 \\
- \\
-\end{array}$ & $\begin{array}{r}32 \\
27 \\
4 \\
1\end{array}$ \\
\hline Abdomen. & $\begin{array}{ll}\text { Lethal } & \text { Iliad } \\
\text { Aeneid } \\
\text { Wounded }- \text { Iliad } \\
\text { Aeneid }\end{array}$ & $\frac{12}{1}$ & $\begin{array}{r}3 \\
2 \\
1\end{array}$ & 二 & $\begin{array}{r}12 \\
2 \\
-\end{array}$ & $\overline{-}$ & $\begin{array}{r}27 \\
4 \\
1 \\
2\end{array}$ \\
\hline Upper limb. & $\begin{array}{ll}\text { Lethal } & \text { Iliad } \\
\text { Aeneid } \\
\text { Wounded }- \text { Iliad } \\
\text { Aeneid }\end{array}$ & $\begin{array}{l}4 \\
- \\
-\end{array}$ & $\begin{array}{l}3 \\
1 \\
2\end{array}$ & $\overline{-}$ & $\frac{4}{2}$ & $\frac{1}{2}$ & $\begin{array}{r}12 \\
1 \\
5 \\
4\end{array}$ \\
\hline Lower limb. & $\begin{array}{ll}\text { Lethal } & \text { Iliad } \\
& \text { Aeneid } \\
\text { Wounded }- \text { Iliad } \\
\text { Aeneid }\end{array}$ & $\frac{3}{-}$ & $\frac{\overline{1}}{1}$ & $\frac{-}{2}$ & $\begin{array}{l}1 \\
1 \\
3 \\
3\end{array}$ & $\frac{1}{2}$ & $\begin{array}{l}5 \\
2 \\
7 \\
6\end{array}$ \\
\hline
\end{tabular}

Table II

Type of weapon causing battle casualties in the " Iliad" and "Aeneid"

\begin{tabular}{l|c|c|c|c|c|c}
\hline \multirow{2}{*}{ Weapon } & \multicolumn{2}{|c|}{ Lethal } & \multicolumn{2}{c|}{ Wounded } & \multicolumn{2}{c}{ Mortality (per cent) } \\
\cline { 2 - 7 } & Iliad & Aeneid & Iliad & Aeneid & Iliad & Aeneid \\
\hline Spearthrust & 94 & 7 & 3 & 1 & 97 & 87 \\
\hline Sword & 39 & 36 & - & 4 & 100 & 90 \\
\hline Stone & 5 & 3 & 6 & - & 41 & 100 \\
\hline Spearcast & 40 & 19 & 17 & 7 & 70 & 73 \\
\hline Arrow & 14 & 5 & 5 & 3 & 74 & 62.5 \\
\hline
\end{tabular}

mentioned in the Aeneid, and was used by the Roman armies during the 2 nd century B.C. ${ }^{3}$.

Injuries from long-range missiles tended to produce a higher ratio of wounded than those from close combat weapons, and consequently the mortality appears to be diminished. From descriptions of actual incidents, once the protective armour had been penetrated by the weapon, all wounds were potentially lethal. The weapons were usually described as being made of bronze, but spears and arrows were often tipped with iron, and therefore were capable of penetrating the protective armour of the enemy ${ }^{4}$. The majority of injuries occurred on the right side of the body, that being the part less likely 
to be protected by the shield ${ }^{5}$, but this may be questioned in the Aeneid (Iliad 26, Aeneid 1), although the numbers of casualties are too few for comment. The back was relatively less protected than the front of the body, so that injuries inflicted on the back were nearly always fatal (Iliad-lethal 9, wounded 1 . Aeneid-lethal 7, wounded nil). Injuries from spears accounted for all the lethal wounds in the back. Obviously it must have been highly dangerous to flee from the enemy on the battlefield, thus exposing the relatively lightly armoured back instead of the more heavily armoured front of the body.

The mortality among the reported casualties during the Siege of Troy was 90 per cent of the total casualties (Table III). Wounds of the head and chest were usually very

Table III

Battle casualties in antiquity: Crude mortality

\begin{tabular}{l|l|r|r|r}
\hline \multirow{2}{*}{ Reference } & \multirow{2}{*}{ Personnel involved } & \multicolumn{3}{c}{ Casualties } \\
\cline { 4 - 5 } & & Total & Died & (Mortality (per cent) \\
\hline Homer " Iliad" & All casualties & 213 & 192 & 90 \\
& Close-range & 147 & 138 & 93.5 \\
& Long-range & 66 & 54 & 82.2 \\
\hline Virgil "Aeneid" & All Casualties & 180 & 164 & 91 \\
& Close-range & 120 & 115 & 96 \\
& Long-range & 60 & 49 & 81.6 \\
\hline
\end{tabular}

severe and frequently were fatal ${ }^{6}$, and abdominal injuries carried a grave prognosis (Table I). Similar comments also apply to the injured mentioned in the Aereid. A comparison between the type of weapon and the distribution of the injury shows a marked variation from the distribution expected from the formula of Hardy and $D u$ Bois $^{7}$. Contrary to expectations, in the Iliad the majority of wounds did not occur on the limbs from long-range weapons (Head/neck 22, Trunk 28, Upper limb 10, Lower limb 9). This is also noted in wounds mentioned in the Aeneid. The distribution may be accounted for by the relatively increased exposure of the upper portions of the body during battle, the lower portions tending to be screened from injury by the bodies of fallen comrades, or being hidden behind barracades or the bulwarks of ships. Such indeed appears to be the case in injuries suffered by the chariotry, where the sides of the chariot provided effective protection from missiles (Table IV), but lack of heavy armour and inability to protect himself while controlling his horses, often exposed the charioteer to fatal wounds (Table V).

The results of injury from close-range weapons are given in Tables I and II. It is also noted that sword wounds were usually fatal, being even more dangerous than thrusts by a spear. There is no evidence that any weapon mentioned in the Iliad inflicted a poisonous wound at the Siege of Troy. During close combat; there is a significant increase in wounds inflicted on the upper part of the body, in comparison to injuries (Iliad and Aeneid-Head/neck 56, Trunk 52, Upper limb 10, Lower limb 5). This variation in distribution certainly suggests that the site of injury is now being influenced by the attacker's decision to aim at the vital areas of the body ${ }^{8}$. Under these circumstances, wounds of the upper limb often appear to have been inflicted mainly as a result of a 
Table IV

Comparison of injuries to infantry and chariotry

\begin{tabular}{|c|c|c|c|c|c|c|c|c|c|c|c|c|c|}
\hline \multirow{2}{*}{\multicolumn{2}{|c|}{ Weapon }} & \multicolumn{2}{|c|}{ Head/neck } & \multicolumn{2}{|c|}{ Chest } & \multicolumn{2}{|c|}{ Abdomen } & \multicolumn{2}{|c|}{ Upper limb } & \multicolumn{2}{|c|}{ Lower limb } & \multicolumn{2}{|c|}{ Total } \\
\hline & & A & B & A & B & A & B & A & B & A & B & A & B \\
\hline Spearthrust: & $\begin{array}{l}\text { Infantry } \\
\text { Chariotry }\end{array}$ & $\begin{array}{r}13 \\
1\end{array}$ & 2 & $\begin{array}{r}16 \\
4\end{array}$ & $\overline{2}$ & $\begin{array}{r}10 \\
2\end{array}$ & - & 2 & - & 3 & - & $\begin{array}{r}44 \\
9\end{array}$ & $\begin{array}{l}2 \\
2\end{array}$ \\
\hline Sword & $\begin{array}{l}\text { Infantry } \\
\text { Chariotry }\end{array}$ & $\begin{array}{r}11 \\
2\end{array}$ & 19 & 1 & $\begin{array}{l}5 \\
2\end{array}$ & $\frac{3}{-}$ & 1 & 3 & $\underline{3}$ & $=$ & 1 & $\begin{array}{r}18 \\
2\end{array}$ & $\begin{array}{r}29 \\
2\end{array}$ \\
\hline Stone-shot & $\begin{array}{l}\text { Infantry } \\
\text { Chariotry }\end{array}$ & $\begin{array}{l}6 \\
1\end{array}$ & 3 & 1 & 二 & 二 & - & $\overline{1}$ & 二 & $\frac{2}{-}$ & - & $\begin{array}{l}9 \\
2\end{array}$ & 3 \\
\hline Spearcast & $\begin{array}{l}\text { Infantry } \\
\text { Chariotry }\end{array}$ & $\begin{array}{r}10 \\
3\end{array}$ & $\stackrel{3}{-}$ & $\begin{array}{l}8 \\
4\end{array}$ & $\begin{array}{r}11 \\
2\end{array}$ & $\begin{array}{r}11 \\
1\end{array}$ & - & $\begin{array}{l}5 \\
1\end{array}$ & 2 & 4 & $\begin{array}{l}1 \\
1\end{array}$ & $\begin{array}{r}38 \\
9\end{array}$ & $\begin{array}{r}17 \\
3\end{array}$ \\
\hline Arrow & $\begin{array}{l}\text { Infantry } \\
\text { Chariotry }\end{array}$ & $\begin{array}{l}1 \\
1\end{array}$ & $\stackrel{3}{-}$ & $\begin{array}{l}1 \\
1\end{array}$ & 1 & 1 & - & $\underline{3}$ & $=$ & $\underline{3}$ & - & $\begin{array}{l}9 \\
2\end{array}$ & 4 \\
\hline
\end{tabular}

Note: $A$ denotes "Iliad" and B" Aeneid".

Table $\mathrm{V}$

Battle casualties of infantry and chariotry/cavalry in the "Iliad" and "Aeneid"

\begin{tabular}{l|c|c|c|c}
\hline \multirow{2}{*}{\begin{tabular}{l}
$*$ \\
\multirow{2}{*}{ Battle }
\end{tabular}} & \multicolumn{2}{|c|}{ Injuries to infantry } & \multicolumn{2}{c}{ Injuries to chariotry/cavalry } \\
\cline { 2 - 5 } & Lethal & Wounded & Lethal & Wounded \\
\hline Iliad & 94 & 24 & 31 & 1 \\
\hline Aeneid & 112 & 14 & 7 & - \\
\hline
\end{tabular}

defensive action whilst attempting to protect a more vulnerable part of the body. Such injuries of the upper limb therefore were not the primary aim of the assailant ${ }^{9}$.

The injuries caused by similar types of weapons to those used in antiquity remained fundamentally unchanged throughout the centuries, until with the advent of gunpowder the anatomical distribution of war wounds changed considerably. The bullet replaced the spear and sword of antiquity ${ }^{10}$, and fragments from high explosive missiles, such as bombs, shells, mortars and grenades (hereafter referred to as H.E. fragments) replaced slingshot, catapults and arrows. Thus in modern warfare close-range personal weapons are swords, knives, bayonets and pistols, most of which have only a very limited application under the conditions of warfare waged during this century ${ }^{11}$. Injuries caused by close-range weapons, although frequently serious, only account for a very small proportion of wounds inflicted during a battle, but may become relatively more common in guerilla warfare (Table VII). Commando units and sabotage groups were more likely to use close-combat weapons. Such injuries were usually almost immediately fatal, and these casualties were therefore seldom seen by hospital personnel. The majority of injuries in battle caused by bombs, shell or gunshot in modern warfare may therefore be classed as injuries from long-range weapons. Compared to those in antiquity, the crude mortality figures of battle casualties in modern warfare show a marked diminution in numbers (Tables III and VI). 
Table VI

More recent battle casualties: Crude mortality

\begin{tabular}{|c|c|c|c|c|}
\hline \multirow{2}{*}{ Reference } & \multirow{2}{*}{ Personnel involved } & \multicolumn{3}{|c|}{ Casualties } \\
\hline & & Total & Died & $\begin{array}{l}\text { Mortality } \\
\text { (per cent) }\end{array}$ \\
\hline $\begin{array}{l}\text { Macleod, Append. H, } \\
\text { p.410 (12) }\end{array}$ & British troops-Crimea & 26,083 & 5,498 & 21.5 \\
\hline MacPhail (12) & Canadian troops-World War I & 122,672 & 51,678 & 42.2 \\
\hline H.M.S.O. (12) & British Army - World War I & $2,216,976$ & 573,507 & 25.8 \\
\hline Crew 1957 (12) & Australian troops-World War II & 2,637 & 516 & 19.5 \\
\hline Crew 1962 (12) & $\begin{array}{l}\text { Normandy troops-World War II } \\
\text { ( } 2 \text { month period) }\end{array}$ & 2,452 & 962 & 39.3 \\
\hline Rees (12) & U.S.A. troops-Korea & 142,091 & 30,928 & 21.7 \\
\hline Rees (12) & Commonwealth troops--Korea & 6,080 & 1,263 & 20.9 \\
\hline $\begin{array}{l}\text { Moffst p.4-5, Tables } \\
1-2(12)\end{array}$ & $\begin{array}{l}\text { British troops on duty- } \\
\text { All casualties } \\
\text { Gun shot wounds only }\end{array}$ & $\begin{array}{r}1,337 \\
694\end{array}$ & $\begin{array}{l}216 \\
127\end{array}$ & $\begin{array}{l}16.2 \\
18.2\end{array}$ \\
\hline
\end{tabular}

Table VII

Injuries from close-range weapons

\begin{tabular}{|c|c|c|c|c|c|c|c|}
\hline \multirow{2}{*}{ Campaign } & \multicolumn{2}{|c|}{ Sword/Lance } & \multicolumn{2}{|c|}{ Bayonet } & \multicolumn{2}{|c|}{ Others } & \multirow{2}{*}{ Total } \\
\hline & Number & $\%$ Wounds & Number & $\%$ Wounds & Number & $\%$ Wounds & \\
\hline $\begin{array}{l}\text { Crimean War-Macleod (12) } \\
\text { Append. 1. p. } 432\end{array}$ & 10 & 17.8 & 46 & 82.1 & & & 56 \\
\hline $\begin{array}{l}\text { Hong Kong 1941-5- } \\
\text { Crew (11) }\end{array}$ & 4 & $0-7$ & 10 & 1.6 & 684 & & 698 \\
\hline $\begin{array}{l}\text { Alamein 1942-Crew (13) } \\
\text { p. } 215\end{array}$ & & - & 120 & 22.4 & 418 & & 538 \\
\hline $\begin{array}{l}\text { Vietnam War-Kovaric et } \\
\text { al (13) }\end{array}$ & & & & & 1397 & 25.1 & 5577 \\
\hline
\end{tabular}

Wounds caused by H.E. fragments do not show a marked diminution of injuries to the head and neck (see Table VIII), suggesting that steel helmets may not provide much protection against this type of weapon at relatively close range, a similar result to that obtained from GSW ${ }^{\mathbf{1 8}}$. However, it must be remembered that these figures only reflect casualties seen by medical personnel behind the front line, and take no account of injuries that were almost immediately fatal. Wounds caused by air or sea bombardments had a relatively low mortality, provided adequate protection was available against direct hits (Table IX). High velocity missiles at close range were dangerous to life, and tended to produce cerebral swelling and gross tissue damage once the skull had been penetrated $^{19}$. It can be seen that in spite of the great increase in explosive power of modern bombs and shells, there has actually been a dimunution in mortality from 
Table VIII

Anatomical distribution of injuries from high explosive fragments and gun shot wounds

\begin{tabular}{|c|c|c|c|c|c|}
\hline Campaign & Weapon & Head/neck & Trunk & Upper limb & Lower limb \\
\hline Crimean War-Macleod (12). Tables 3-4 & GSW & 1816 & 1504 & \multicolumn{2}{|c|}{5023} \\
\hline Hong Kong 1941-5. Crew (11). p.31-34 & GSW & 112 & 117 & 208 & 247 \\
\hline Alamein 1942_-.Crew (13) & GSW & 57 & 67 & \multicolumn{2}{|c|}{294} \\
\hline Sicily 1943-Crew (15). Table 21 & GSW & 134 & 177 & 347 & 424 \\
\hline Normandy 1944 -Crew (15). Table III & GSW & 140 & 254 & 212 & 260 \\
\hline Vietnam War-Kovaric et al (12) & GSW & 112 & 277 & 282 & 422 \\
\hline $\begin{array}{l}\text { Northern Ireland 1971-4. Moffat (12) } \\
\text { p. 4-5 } \\
\text { Malta } 1940-3 \text {. Crew (15). p. } 630-1 \text {. Series } 1 \\
\text { Series } 2\end{array}$ & $\begin{array}{l}\text { GSW } \\
\overline{\text { Bomb }}-\overline{-}- \\
\text { Bomb }\end{array}$ & $\begin{array}{c}123 \\
---\overline{5} \\
178\end{array}$ & $\begin{array}{r}181 \\
110 \\
11\end{array}$ & \multicolumn{2}{|c|}{390} \\
\hline Normandy 1944 -Crew (15). Table III & $\begin{array}{l}\text { Shell } \\
\text { Mortar } \\
\text { Bomb }\end{array}$ & $\begin{array}{r}259 \\
113 \\
23\end{array}$ & $\begin{array}{r}279 \\
118 \\
35\end{array}$ & $\begin{array}{r}222 \\
132 \\
26\end{array}$ & $\begin{array}{r}402 \\
181 \\
26\end{array}$ \\
\hline Vietnam War. Kovaric et al (13) & H.E. & 242 & 388 & 375 & 502 \\
\hline
\end{tabular}

Table VIIIa

Anatomical distribution of injuries from high explosive fragments and gun shot wounds

\begin{tabular}{|c|c|c|c|}
\hline Campaign & Weapon & Total & $\begin{array}{l}\text { Head/neck injuries } \\
\text { (percentage) }\end{array}$ \\
\hline Crimean War & GSW & 8343 & 21.7 \\
\hline Hong Kong 1941-1945 & GSW & 684 & 17.8 \\
\hline Alamein 1942 & GSW & 418 & 13.7 \\
\hline Sicily 1943 & GSW & 1082 & 12.4 \\
\hline Normandy 1944 & GSW & 866 & 16.2 \\
\hline Vietnam War & GSW & 1093 & 10.2 \\
\hline $\begin{array}{l}\text { Northern Ireland } \\
\text { Malta 1940-1943. } \\
\text { Series } 1 \\
\text { Series } 2\end{array}$ & $\begin{array}{c}\text { GSW } \\
\text { Bomb } \\
\text { Bomb }\end{array}$ & $\begin{array}{c}694 \\
-\frac{-103}{629}\end{array}$ & $----\frac{17.7}{17.3}-\ldots-$ \\
\hline Normandy 1944 & $\begin{array}{l}\text { Shell } \\
\text { Mortar } \\
\text { Bomb }\end{array}$ & $\begin{array}{r}1142 \\
544 \\
110\end{array}$ & $\begin{array}{l}22.6 \\
20.7 \\
20.9\end{array}$ \\
\hline Vietnam War & H.E. fragments & 1507 & 15.8 \\
\hline
\end{tabular}

wounds caused by these weapons, which reflects advances in surgical technique, so that when cases reached the operating table quickly, they stood a good chance of survival. 
Table IX

Mortality from shells and bombs

\begin{tabular}{|c|c|c|c|c|}
\hline Campaign & Weapon & Killed & Total & $\%$ Mortality \\
\hline World War I. Statistics (16) & $\begin{array}{l}\text { Airship } \\
\text { Aeroplane } \\
\text { Sea bombardment }\end{array}$ & $\begin{array}{l}556 \\
857 \\
157\end{array}$ & $\begin{array}{r}1913 \\
2907 \\
791\end{array}$ & $\begin{array}{l}29.5 \\
29.4 \\
19.8\end{array}$ \\
\hline $\begin{array}{l}\text { World War II. Malta. Crew } \\
1956(15) \text {. p. } 630\end{array}$ & Aeroplane & 25 & 209 & 12.0 \\
\hline $\begin{array}{l}\text { World War II. Normandy. Crew } \\
1962 \text { (12). Table III }\end{array}$ & H. E. fragments & 606 & 2337 & 25.9 \\
\hline $\begin{array}{l}\text { Northern Ireland. Moffat (12). } \\
\text { Table } 3\end{array}$ & $\begin{array}{l}\text { Explosive device } \\
\text { (home made) }\end{array}$ & 81 & 343 & 23.6 \\
\hline
\end{tabular}

Table X

Anatomical distribution of GSW injuries ( $\%$ incidence) for comparison

\begin{tabular}{l|c|c|c|c}
\multicolumn{1}{c|}{ Campaign } & Head/neck & Trunk & Upper limb & Lower limb \\
\hline Trojan War - Long-range weapons (Homer) & 36.8 & 39.7 & 13.2 & 10.3 \\
Aeneid $\quad$ Long-range weapons (Virgil) & 25.7 & 51.6 & 5.6 & 17.1 \\
\hline Franco-Prussian War. Fröhlich (10) & 9.0 & 21.0 & 26.0 & 44.0 \\
\hline World War II. Sicily. Crew 1959 (15) & 12.3 & 16.3 & 32.0 & 39.4 \\
$\quad$ Hong Kong. Crew (11) (12). Table III & 18.4 & 17.1 & 30.5 & 36.0 \\
$\quad$ Normandy. Crew 1962 (12.0 & 10.2 & 25.2 & 25.8 & 38.6 \\
\hline Vietnam War. Kovaric et al (13) & 17.7 & 26.1 & \multicolumn{2}{|c}{56.2} \\
\hline Northern Ireland 1971/1974. Moffat (12) & & & &
\end{tabular}

The distribution of injuries from GSW (Table $X$ ) followed the expected ratio according to Hardy and $D u B o i s^{7}$ in the majority of cases, but accurate and selective rifle fire at close range has invalidated this statement for casualties in Northern Ireland ${ }^{18}$. In these cases, close range sniper fire from high velocity weapons, deliberately aimed to cause damage to the vital organs of chest and head, produced a very high mortality ${ }^{18}$. The mortality from GSW of the head is high, but can be considerably reduced in selected cases when adequate surgical facilities are quickly available (Table XI). The majority of war wounds occur on the limbs, which are not now provided with protective armour. Fortunately the mortality from such injuries is relatively slight ${ }^{21}$. The drop in mortality from war wounds reflects the importance of immediate surgical treatment, and this is particularly noticeable in penetrating injuries involving skull and brain (Table XII) ${ }^{22}$. In such cases, the mortality has continued to diminish in direct relationship to the availability of prompt surgical treatment and the proper use of antibiotics. With the advent of automatic and semi-automatic weapons, GSW tend to be multiple, thereby increasing the severity of the injury. The selection of a definite target has thus tended to become less important to the assailant, whereas prompt surgical treatment has become vital for preserving the life of the victim ${ }^{23}$. In antiquity the treatment of severe injuries 
Table XI

Mortality of head injuries from GSW and HE fragments

\begin{tabular}{|c|c|c|c|c|}
\hline Group & Total & Deaths & $\%$ Mortality & Cause \\
\hline $\begin{array}{l}\text { Crimean War-Soldiers. } \\
\text { Macleod (17) }\end{array}$ & $\begin{array}{r}898 \\
72\end{array}$ & $\begin{array}{r}178 \\
72\end{array}$ & $\begin{array}{r}19.9 \\
100.0\end{array}$ & $\begin{array}{l}\text { GSW all types } \\
\text { GSW penetrating }\end{array}$ \\
\hline Boer War-Soldiers. Makins (17) & 10 & 8 & 80.0 & GSW all types \\
\hline $\begin{array}{r}\text { World War I-Soldiers. Cushing (17) } \\
\text { Series 1 } \\
\text { Series 2 } \\
\text { Series 3 }\end{array}$ & $\begin{array}{l}44 \\
44 \\
45\end{array}$ & $\begin{array}{l}24 \\
18 \\
13\end{array}$ & $\begin{array}{l}54.5 \\
40.9 \\
28.8\end{array}$ & $\begin{array}{l}\text { Mainly H.E. fragments } \\
\text { Mainly H.E. fragments } \\
\text { Mainly H.E. fragments }\end{array}$ \\
\hline World War II-Soldiers. Eden (14) & 258 & 37 & 14.4 & $\begin{array}{l}\text { Penetrating GSW and } \\
\text { H.E. fragments }\end{array}$ \\
\hline Normandy-Soldiers. Crew 1962 (14) & $\begin{array}{l}140 \\
414\end{array}$ & $\begin{array}{l}61 \\
89\end{array}$ & $\begin{array}{l}43.6 \\
21.6\end{array}$ & $\begin{array}{l}\text { GSW } \\
\text { H.E. fragments }\end{array}$ \\
\hline $\begin{array}{r}\text { Korean War-Soldiers. Hammon (14) } \\
\text { Civilians. Hammon(14) }\end{array}$ & $\begin{array}{r}132 \\
1008 \\
54 \\
503\end{array}$ & $\begin{array}{l}30 \\
77 \\
16 \\
67\end{array}$ & $\begin{array}{r}22.7 \\
7.6 \\
29.6 \\
13.3\end{array}$ & $\begin{array}{l}\text { GSW } \\
\text { H.E. fragments } \\
\text { GSW } \\
\text { H.E. fragments }\end{array}$ \\
\hline $\begin{array}{l}\text { Northern Ireland-Soldiers } \\
\text { Moffat (23) } \\
\text { Gordon (24) }\end{array}$ & $\begin{array}{l}87 \\
93\end{array}$ & $\begin{array}{l}46 \\
53\end{array}$ & $\begin{array}{l}53.0 \\
56.0\end{array}$ & $\begin{array}{l}\text { GSW } \\
\text { GSW }\end{array}$ \\
\hline
\end{tabular}

Table XII

Mortality from penetrating injuries of the skull

\begin{tabular}{|c|c|c|c|}
\hline Campaign & Reference & $\%$ Mortality & Comments \\
\hline Trojan War & Homer "Iliad" & 92.0 & \\
\hline Conquest of Italy & Virgil " Aeneid" & 88.2 & \\
\hline Crimean War & Macleod (17) & 100.0 & GSW hospital cases only \\
\hline American Civil War & Otis (25) & 81.0 & GSW and H.E. fragments \\
\hline World War I & $\begin{array}{ll}\text { Cushing (17) } & \begin{array}{l}\text { Series 1 } \\
\text { Series 2 } \\
\text { Series 3 }\end{array} \\
\text { Jefferson (26) } & \end{array}$ & $\begin{array}{l}54.5 \\
40.9 \\
28.8 \\
37.6\end{array}$ & $\begin{array}{l}\text { Mainly H.E. } \\
\text { Fragments hospitalised } \\
\text { Mainly H.E. fragments }\end{array}$ \\
\hline World War II & $\begin{array}{l}\text { Eden (13) } \\
\text { Crew } 1962(15)\end{array}$ & $\begin{array}{l}23.6 \\
27.2\end{array}$ & $\begin{array}{l}\text { GSW and H.E. fragments } \\
\text { GSW and H.E. fragments }\end{array}$ \\
\hline Vietnam War & $\begin{array}{l}\text { Hammon (14) } \\
\text { Kovaric et al (28) }\end{array}$ & $\begin{array}{l}22.7 \\
29.4\end{array}$ & $\begin{array}{l}\text { GSW hospital cases only } \\
\text { Mainly H.E. fragments }\end{array}$ \\
\hline Northern Ireland & $\begin{array}{l}\text { Moffat (23) } \\
\text { Byrnes et al (27) }\end{array}$ & $\begin{array}{l}53.0 \\
68.0 \\
85.0\end{array}$ & $\begin{array}{l}\text { GSW only } \\
\text { GSW traversing front to back } \\
\text { of skull } \\
\text { GSW traversing side to side } \\
\text { of skull }\end{array}$ \\
\hline
\end{tabular}

was primitive, and the evacuation of casualties often delayed. It is not surprising therefore that wounds of the head from close-range weapons had such a high mortality (Table I). 
Injuries of the abdomen also carried a bad prognosis in antiquity, but the advent of rapid evacuation, combined with judicious surgery and the use of antibiotics has markedly changed the picture in modern warfare (Table XIII).

Table XIII

Mortality from severe GSW of abdomen

(for comparison)

\begin{tabular}{l|l|c|c|c}
\hline \multicolumn{1}{c|}{ Campaign } & \multicolumn{1}{c|}{ Reference } & Total & Died & $\%$ Mortality \\
\hline Trojan War & $\begin{array}{l}\text { Homer “ Iliad ", cf. Table I } \\
\text { All types of weapons }\end{array}$ & 28 & 27 & 96.5 \\
\hline Conquest of Italy & $\begin{array}{l}\text { Virgil "Aeneid ", cf. Table I } \\
\text { All types of weapons }\end{array}$ & 6 & 4 & 66.6 \\
\hline Crimean War & Macleod (29) & 55 & 51 & 93.0 \\
\hline Boer War & Makins (30) & 15 & 11 & 73.3 \\
\hline Normandy 1944 & Crew (31). Wounds of trunk & 264 & 192 & 72.6 \\
\hline Vietnam War & Kovaric et al (32) & 108 & 25 & 23.2 \\
\hline Northern Ireland & Moffat (33) & 63 & 20 & 31.8 \\
\hline
\end{tabular}

\section{Acknowledgement}

I wish to thank Professor M. S. Owen-Smith for the help he has given to me in the presentation of this article.

\section{BIBLIOGRAPHY}

1 F. H. Stubbings, " the recession of Mycenean civilisation: the Trojan War", in I. E. S. Edwards, C. J. Gadd, N. G. L. Hammond, E. Sollberger (Ed.), Camb. Anc. Hist. 2.(2). Cambridge, University Press, 1975, 3rd ed., p.342-350, see p.343, 350.

G. S. Kirk, "the Homeric poems as history: conclusion", in I. E. S. Edwards et al. (Ed.), ibid, p.849-850. The Homeric epic was probably basically true (D. L. Page, "Homer and the Trojan War'J. Hellen. Stud. 1964. 84. 17-20, see p.19).

J. H. Breasted, Edwin Smith Papyrus. O.I.C.3. Vol. 1. Chicago, University of Chicago Press, 1930. see Pl. II, figs, 3-5; Pl. VII, figs. 14-16; Pl. VIII, figs. 17, 18.

$3 \quad$ Homer, Iliad. $3.18 ; 6.104-5 ; 11.43 ; 12.298,465 ; 13.241 ; 16.139 ; 21.144-5$.

Virgil, Aeneid. $1.313 ; 5.557 ; 8.661-2 ; 9.402,418,586 ; 10.882-3 ; 11.650 ; 12.488-9,615$.

Polybius, The Histories. V1. 22.1-2; 23.8-9.

A. M. Snodgrass, Arms and Armour of the Greeks, London, Thames and Hudson, 1967, see p.39.

4 Macrobius, Saturnalia. 7.16.34, noted that Aristotle (Problemata. 1.16) commented on wounds from bronze swords being less harmful, and were treated more readily, than those from iron swords. In antiquity, not all soldiers wore protective armour, e.g. the Locrians and the followers of Amphius (Iliad. 2.527-9,830; 13.712-6). Note the ineffectual stroke of a bronze sword (Iliad. 3.361-3).

5 H. Lipshutz, ' hand, arm and shoulder trauma in the Iliad', Surgery. 1963. 54, 833-6.

6 A. A. Teulón, " la cirugia Homerica ', Episteme. 1971. 5. 83-97, see p.96.

7 J. D. Hardy and E. F. Du Bois ("the technique of measuring radiation and convection ', Jour. Nutr. 1938. 15. 461-475, see p.466) calculated the proportions of surface contributed to the whole body as:-head 7, upper limb 19, lower limb 39, trunk 35 of the total surface area of 100. 
F. A. E. Crew, History of the Second World War. The Army Medical Services. London, H.M.S.O. Campaigns II. 1957. p.31-4, Table 4 . Hospital reports indicated only $2.3 \%$ of the wounded received injuries from close-range weapons. But note the injuries received from various home-made explosive devices in Northern Ireland casualties (W. C. Moffat, 'British forces casualties in Northern Ireland ', J. roy. Army med. Cps. 1976. 112. 3-8, see Tables 2-3).

12 G. H. B. Macleod, Notes on the surgery of the war in the Crimea, London, J. Churchill, 1858, see p.46 Table 1; p.417-8 Appendix I, Tables 3-4. Hospital cases only.

A. MacPhail, the official history of the Canadian Forces in the Great War 1914-1919, the medical services. Ottawa, 1925, see p.249, 396. All types of war wounds included.

General annual reports on the British Army for the period from 1st Oct. 1913 to 30th Sept. 1919 (Cmd. 1193). H.M.S.O., 1920. Part IV-war casualties, p.62-72, Tables IA-IG.

Crew, 1957, ibid, p.106. Deaths in battle for a 2-month period.

Crew, 1962, ibid, Campaigns IV, p.631-2 Table 111. Deaths in battle for a 2-month period.

D. Rees, Korea the limited war. London, MacMillan, 1964, p.460-1 Appendix C.

Moffat, ibid, see Tables 2-7, and p.4-5 Tables 1-2 for corrected battle figures.

19 Crew, 1957, ibid, p.215. Casualties from other weapons not specified.

J. J. Kovaric, H. F. Hamit, R. M. Hardaway, 'Vietnam casualty statistics ', Arch. Surg. 1969. 98. 150-2, see p.151 Table 1. Mixed group of injuries from close-range weapons.

W. H. Hammon, ' analysis of 2187 consecutive penetrating wounds of the brain from Vietnam ', J. Neurosurg. 1971. 34. 127-131, see p.131 Table 5.

$\mathrm{K}$. Eden, 'mobile neurosurgery in warfare. Experiences in the Eighth Army's campaign in Cyrenaica, Tripolitania and Tunisia ', Brit. J. Surg. 1944. 31. 324-8, see Table 3.

16 Crew, 1956, op. cit., see note 11. Campaigns I. p.630-1.

Crew, 1959, ibid, Campaigns III. p.81-4 Table 21.

Crew, 1962, op.cit., see note 12.

World War I: Statistics of the military effort of the British Empire during the Great War. 1914-1920. H.M.S.O. 1922, p.678.

17 Macleod, op. cit., see note 12, p.419.

G. H. Makins, Surgical Experiences in South Africa. 1899-1900. London, Smith, Elder and Co., 1901, p.290.

Kovaric et al., op. cit., see note 13, p.150.

H. Cushing, 'notes on penetrating wounds of the brain', Brit. Med. J. 1918. 1. 221-6.

18 P. Meid and J. M. Yinling, U.S. Marine operations in Korea, 1950-1953. Vol. V: operations in West Korea. Washington D.C., Historical Divisions, H.Q.U.S. Marine Corps, 1972, p.140, 484. Body armour and steel helmets markedly reduced casualties in Korea, particularly those of chest and abdomen. Estimated at least $30 \%$ reduction in severe casualties due to protection by body armour. Steel helmets certainly protected from serious head injuries from spent bullets (see also W. E. Mathews, ' the early treatment of craniocerebral missile injuries: experience with 92 cases', J. Trauma, 1972. 12. 939-954, see p.953).

Moffat, op. cit., see note 11, p.6 Tables 5 and 6, who shows a high mortality from head and neck injuries due to GSW at relatively close range.

J. E. Webster, R. C. Schneider, J. E. Lofstrom, 'observations on early type of brain abscess following penetrating wounds of the brain', J. Neurosurg. 1946. 3. 7-14. Bone splinters and contaminated debris from the exterior are main causes of secondary infection, for which early treatment in hospital is important.

Makins, op. cit., see note 17, p.262, 289. At short ranges, the immediate prognosis was uniformly bad with a high death rate.

Moffat, ibid, p.5. The number of casualties from high velocity missiles in Northern Ireland was unknown, but probably was quite high.

E. S. Gurdjian, "the treatment of penetrating wounds of the brain sustained in warfare J. Neurosurg. 1974. 40. 157-167, see p.166.

Hammon, op. cit., see note 14 . Of 455 terminal cases 165 had GSW of the head $(36.26 \%)$, of 1732 operative cases only $186(10.65 \%)$ had GSW. Effects of prompt surgical treatment are strikingly shown by the high mortality of casualties during withdrawals under fire from advancing enemy troops in Korea, when all medical treatments were difficult to obtain (R. E. Appleman, South to the Naktong, North to the Yalu (June-Nov. 1950). Washington D.C., Office of the Chief of Military History, 1961, p.195, 203, 221).

Kovaric et al., op. cit., see note $13.42 \%$ of all wounds were localised to the limbs, but mortality rate was low.

Macleod, op. cit., see note 12, p.414 Appendix I. GSW of upper limb had 3.25\% mortality, of the lower limb $8.05 \%$.

Moffat, op. cit., see note 11, Table 6. Mortality from wounds of the limbs in Northern Ireland was $0.26 \%$. 
Mathews, op.cit., see note 18, p.939.

Appleman, op. cit., see note 20.

Moffat, ibid, see p.6 Table 5.

Moffat, ibid.

D. S. Gordon, ' Surgery of violence V. Missile wounds of the head and spine '. Br. Med. J. 1975. 1. $614-6$, see p.615.

G. A. Otis. The medical and surgical history of the war of the rebellion. Part First. Surgical Volume. Washington D.C. Govt. Print. Off. 1875, p.307-8.

G. Jefferson, 'physiological pathology of GSW of the head', Br. J. Surg. 1919. 7. 262-289, see p.266.

D. P. Byrnes, H. A. Crockard, D. S. Gordon, C. A. Gleadhill, ' penetrating cranio-cerebral missile injuries in the civil disturbances in Northern Ireland', Br. J: Surg. 1974. 61. 169-176, see p.174 Table IV.

Kovaric et al., op, cit., see note 13, p.150-152.

Macleod, op. cit., see note 12, p.426.

Makins, op. cit., see note 17, p.449.

Crew, 1962, op. cit., see note 12 .

Kovaric et al., op. cit., see note 13, p.151 Table 1, p.152 Table 4.

Moffat, op. cit., see note 23.

\section{ACADEMIC ACHIEVEMENTS}

F.F.C.M. BRIGADIER W. S. MILLAR, M.F.C.M., L.R.C.P., L.R.C.S., L.R.F.P.S., D.T.M.\&H., D.P.H., D.I.H., Late R.A.M.C.

F.R.C.P.(Ed.) Lieutenant-Colonel D. E. Bradford, M.B., Ch.B., M.R.c.P., D.t.M.\&H., R.A.M.C.

F.R.C.P.

LIEUTENANT-COLONEL W. M. RoBINSON, M.B., B.Ch., B.A.O., M.R.C.P., D.T.M.\&H., R.A.M.C.

F.F.A.R.C.S. $\quad$ MAJOR R. S. P. TAMLYN,"M.B.E., M.B., B.S., M.R.C.S., L.R.C.P., R.A.M.C.

F.R.C.O.G.

Colonel W. A. KirkPatrick, M.B., B.Ch., B.A.O., M.R.C.o.G., D.obst.R.c.o.G., Late R.A.M.C. COLONEL J. F. O'KelLY, M.B., B.ch., M.A.O., M.R.C.O.G., D.obst.R.C.O.G., Late R.A.M.C. LIEUTENANT-COLONEL J. F. S. BATSON, M.B., B.S., M.R.C.O.G., D.obst. R.C.O.G., R.A.M.C. LIEUTENANT-COLONEL G. M. JOHNSTONE, M.B., Ch.B., M.R.C.o.G., D.obst.R.C.o.G., R.A.M.C. LIEUTENANT-Colonel L. W. PADGETT, M.B., B.S., F.R.C.S., M.R.C.o.G., D.T.M.\&H., R.A.M.C. CAPTAIN D. W. SMTTH, M.B., Ch.B., R.A.M.C.

M.R.C.O.G. CAPTAIN K. R. YOUNG, M.B., B.S., R.A.M.C.

M.R.C.G.P. MAJOR J. P. HERBERT, M.B., B.S., D.obst.R.C.o.g., R.A.M.C. MAJOR R. D. LuPTON, M.B., Ch.B., D.obst.R.C.O.G., R.A.M.C. MAJOR D. D. McBRIDE, M.B., ch.B., D.obst. R.C.O.G., R.A.M.C. MAJOR P. H: RHEINHOLD, M.R.C.S., L.R.C.P., R.A.M.C. MAJOR J. Wictome, M.B., Ch.B., R.A.M.C. CAPTAIN I. D. Almond, M.B., B.S., R.A.M.C. CAPTAIN C. W. LYON-DEAN, M.B., Ch.B., R.A.M.C.

D.Obst.R.C.O.G. Captain J. Carroll, M.B., B.S., M.R.C.S., L.R.C.P., R.A.M.C. CAPTAin M. A. TetTenBORN, M.B., ChB., M.R.C.P., D.C.H., R.A.M.C.

Diploma in Lieutenant-Colonel D. P. J. MurRay, M.B., Ch.B., M.R.C.P., R.A.M.c. Venereology 